\title{
Proximate, Microbial and Sensory Characteristics of Cowpea Milk Fermented with Probiotic Starter Cultures
}

\author{
Kevin Omondi Aduol, Arnold N. Onyango, Samuel M. Imathiu
}

\begin{abstract}
Fermentation of cowpea milk was carried out using three mixed starter cultures containing (i) Lactobacillus acidophilus, Bifidobacterium spp, and Streptococcus thermophilus (ABT) (ii) Lactobacillus delbrueckii subsp. bulgaricus and Streptococcus thermophilus (DT) or (iii) Lactobacillus rhamnosus GR-1 and Streptococcus thermophilus (GT). Proximate composition of raw and fermented cowpea milk was determined using the AOAC methods. Lactic acid bacteria survival and sensory attributes of the fermented cowpea milk was also determined. Crude fat decreased significantly $(P<\mathbf{0 . 0 5})$ after fermentation except for GT culture which led to $33.2 \%$ increase. Crude fiber was not detected in all the samples. Fermentation with GT also led to increase in protein content, although this was not significant. A decrease was observed for carbohydrate content, after fermentation, with DT culture leading to the highest decrease of $7.1 \%$. There was a general increase in microbial growth during the first two weeks of storage (refrigeration at $4^{\circ} \mathrm{C}$ ). Thereafter the number reduced to $\log 104.11 \mathrm{cfu} / \mathrm{ml}$ on the 28th day of storage. No significant differences were observed for sensory attributes of taste, texture and overall acceptability. However, aroma and appearance had significant differences among the samples $(\mathbf{P}<\mathbf{0 . 0 5})$. The study demonstrated that nutritional quality of cowpea milk can be achieved through fermentation. Also, cowpea milk fermented with lactic acid bacteria produce a yoghurt-like product that can be sweetened to taste and be acceptable to consumers. The study therefore recommends that more work should be done to improve the sensory acceptability of the products and that their potential health benefits should be determined through in vivo studies.
\end{abstract}

Index Terms - Cowpeas, cowpea milk, fermentation, probiotics.

\section{INTRODUCTION}

In developing countries, chronic protein deficiency is a major problem and increasing cases of malnutrition and many infant deaths have been attributed to it [1]. Noncommunicable diseases such as diabetes and cardiovascular diseases are also increasing in prevalence throughout the world, and especially in low income countries [2]-[3]. One of the recommended strategies for reversing this trend is adoption of health-promoting diets particularly plant-based foods [4]-[5]. Cowpea is one of the most popular legumes

Published on July 22, 2020.

Kevin Omondi Aduol, School of Agriculture and Biotechnology, University of Eldoret, Kenya.

(email: kevinaduol@yahoo.com)

Arnold N. Onyango, School of Food and Nutrition Sciences, Jomo Kenyatta University of Agriculture and Technology, Kenya.

(email: arnold.onyango@jkuat.ac.ke)

Samuel M. Imathiu, School of Food and Nutrition Sciences, Jomo Kenyatta University of Agriculture and Technology, Kenya.

(email: samuel.imathui@jkuat.ac.ke) consumed in Kenya, both as a vegetable and as a grain but most consumers have reported occurrence of intestinal gas or flatulence after legume consumption [6] which often hinders utilization. Fermentation, especially through utilization of probiotic microorganisms is one method that can be used to enhance cowpeas consumption because it helps remove the beany flavor and the anti-nutrients that cause flatulence [7]. Microorganisms used for fermentation of food products are capable of producing a remarkable spectrum of products and bioactive components that enhance the biofunctionality of the food products and develop desirable properties such as flavor, aroma and texture [8]. Lactic acid bacteria (LAB) are the most commonly used microorganisms for fermentation because of their safe metabolic activity while growing in foods utilizing available sugar for the production of useful metabolites such as amino acids, enzymes, vitamins, organic acids and alcohols [9]. Probiotic foods are a major class of nutraceuticals which contain high populations of healthpromoting microorganisms that can survive in the human digestive tract [10]. In the colon, they have been shown to suppress multiplication of pathogens which can reduce the incidences of microbial foodborne illnesses [11]. Some of these microbes' metabolites including short chain fatty acids including propionic acid and butyric acid have been demonstrated to have health benefits such as promoting apoptosis of colon cancer cells, and reducing the risk for insulin resistance, diabetes and atherosclerosis [2].

Legumes including cowpeas have a high potential as functional foods. Some studies have reported that cowpea have a potential for reducing of chronic diseases such as gastrointestinal diseases, cardiovascular diseases, diabetes and some types of cancers, and this may be partly due to bioactive peptides and phenolic substances [12]. However, cowpea consumption is associated with flatulence and other abdominal discomforts in some individuals [13]. The raffinose family oligosaccharides such as raffinose, stachyose and verbascose present in cowpea in relatively large amounts are considered to contribute to flatulence [14]. On the other hand, these oligosaccharides are also considered to be beneficial as prebiotics, which can promote the growth of probiotic bacteria [15].

This study was therefore intended to determine the suitability of cowpea milk for the growth of different probiotic bacteria, associated chemical changes induced by such fermentation of cowpea milk, and the sensory acceptability of the fermented cowpea milk. Cowpea milk was fermented with three mixed lactic acid bacteria starter cultures. All the cultures contained Streptococcus thermophilus, and, in addition, one of the cultures contained Lactobacillus delbrueckii susb bulgaricus, the second 
contained Lactobacillus rhamnosus GR-1 strain, and the third contained Lactobacillus acidophilus and Bifidobacterium sp. All these bacteria have previous claims of probiotic effects [16-17].

\section{MAterials AND Methods}

\section{A. Raw material acquisition}

Five kilograms of M66 variety cowpeas were purchased from a local market in Nairobi, Kenya. The cowpeas were packaged in an eco-friendly recyclable paper bag and transported to the laboratory, where they were kept in a lockable cabinet at room temperature awaiting experiment.

\section{B. Probiotic starter cultures}

Three probiotic cultures namely ABT-5 (Lactobacillus acidophilus La-5 + Bifidobacterium animalis Bp-12+ Streptococcus thermophilus), YFL-903 (Streptococcus thermophilus + Lactobacillus bulgaricus subs. debulgaricus) (DT) and Yoba Fiti (Lactobacillus rhamnosus GR-1 + Streptococcus thermophilus) (GT), were obtained from ProLab Limited, Nairobi, Kenya and used for the fermentation of cowpea milk. The starter cultures were purchased in frozen form in sachets and stored according to manufactures instructions. They were stored at $-4^{\circ} \mathrm{C}$ in a freezer prior to use except Yoba GR-1 that was kept at room temperature $\left(20-25^{\circ} \mathrm{C}\right)$.

\section{Preparation of cowpea milk}

Cowpeas $(400 \mathrm{~g})$ were soaked for 12 hours in 4 liters of distilled water at room temperature $\left(20^{\circ} \mathrm{C}-25^{\circ} \mathrm{C}\right)$. The steeping water was decanted and the cowpeas washed with tap water then dehulled completely by hand. Boiling water was used for blending (Von Hotpoint Blender, HB241CW), in the ratio of $1: 10(\mathrm{w} / \mathrm{v})$ for 3 minutes at high speed followed by filtration through a cheese cloth. This blending ratio resulted into 4 liters of cowpea milk. The resulting filtrate was pasteurized at $70^{\circ} \mathrm{C}$ and the temperature held for 20 minutes [18]. Heating was done while stirring frequently to prevent the content from sticking on the equipment. The milk was allowed to cool to an incubation temperature of $45^{\circ}$ $\mathrm{C}$ and then divided into four portions of 1 liter each.

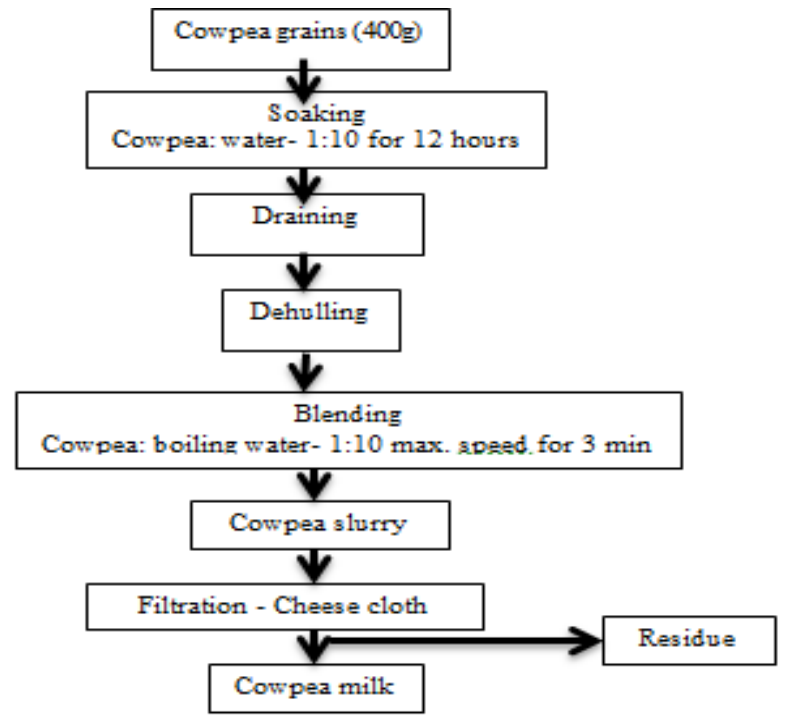

Fig. 1. Cowpea milk preparation flow diagram. Source: modified from [18].

\section{Preparation of fermented cowpea milk}

Having divided the cowpea milk into four portions of 1 liter each, every culture was added to a portion, leaving one portion without a culture added to it. This was the control during fermentation. A $2.0 \mathrm{~g}$ of each culture was poured onto a teaspoon and added directly to the cowpea milk, in 2-liter capacity stainless steel containers, while stirring according to the manufacturer's instructions. The portions of the cowpea milk were then incubated in an electric incubator; model IB-09 (Mitamura Riken Kogyo MRK Inc. Japan) at $45^{\circ} \mathrm{C}$ anaerobically for 14 hours. Three independent fermentations were done for to ensure replications.

\section{E. pH measurement of fermented cowpea milk}

The $\mathrm{pH}$ of the incubated milk was monitored during fermentation after every 2 hours in order to study the $\mathrm{pH}$ changes and to determine the optimum fermentation time for the cultures under investigation. The $\mathrm{pH}$ was determined at room temperature $\left(20^{\circ} \mathrm{C}-25^{\circ} \mathrm{C}\right)$ using a digital $\mathrm{pH}$ meter (HANNA, H18519N). The $\mathrm{pH}$ meter was calibrated with buffer standards of $\mathrm{pH} 4.0$ and $\mathrm{pH} 7.0$ before use. The measurements were taken in triplicate and average values calculated.

\section{F. Lactic Acid Bacteria survival determination during storage of fermented cowpea milk}

Changes in the bacteria counts during storage were determined by modified AOAC (2000) methods. Lactobacillus MRS Agar and M17 Agar Base were used for Yoba Gr-1 and ABT-5, respectively. YF-L 903 needed modification of the MRS Agar with $0.05 \%$ L. cysteine. For probiotic counts, $0.3 \mathrm{ml}$ of fusidic acid was added into 500 $\mathrm{ml}$ MRS agar and mixed thoroughly before pouring into plates. The plates were then incubated at $30^{\circ} \mathrm{C}$ in an incubator for 24 hours. Survival of probiotic microorganisms in the fermented cowpea milk was monitored for a period of 28 days and plating was done weekly. Fusidic acid was used for quality control to confirm presence of probiotic microorganisms in the fermented cowpea milk. Plates with $\leq 300$ colonies were counted and the number of viable cell concentrations expressed in colony forming units $(\mathrm{CFU}) / \mathrm{ml}$ of the fermented milk using the formula from International Dairy Federation method [19] as follows:

$$
\log C=\sum x / n 1+(0.1 n 2) x d
$$

\section{G. Proximate analyses of fermented cowpea milk}

Proximate analyses of samples: ash, moisture, crude fiber and protein content were performed according to Association of Official Analytical Chemist (AOAC) official methods 923.03, 925.09, 978.10 and 979.09 [20]. Percentage nitrogen was determined using Micro-Kjeldahl method then converted to crude protein by multiplying with a standard factor of 6.25 [21]. Total lipids were determined by modified Bligh and Dyer method [22]. The carbohydrate concentration was determined by difference between 100 and total sum of the percentage of ash, moisture, fiber, fat and protein [21]. All the analyses were performed in triplicates. 


\section{H. Determination of mineral concentration}

Atomic absorption spectroscopy (AAS AA-7000, Shimadzu Cop. Japan) was used to determine the minerals; iron, zinc, calcium and magnesium [20]. A $5 \mathrm{ml}$ aliquot of sample in a $100 \mathrm{ml}$ volumetric flask and $50 \mathrm{ml}$ of $24 \%(\mathrm{w} / \mathrm{v})$ tricarboxylic acid (TCA) was mixed. The samples were shaken for 30 minutes at 5 min intervals and filtered using Whatman filter paper No. 1 . To a $5 \mathrm{ml}$ aliquot of the filtrate transferred to a volumetric flask, $1 \mathrm{ml}$ of $5 \%(\mathrm{w} / \mathrm{v})$ lanthanum solution were added and made to volume with distilled water. A mixed standard containing $5.0 \mathrm{mg} / \mathrm{l} \mathrm{Fe}$, $5.0 \mathrm{mg} / \mathrm{l} \mathrm{Ca}, 0.6 \mathrm{mg} / \mathrm{l} \mathrm{Mg}, 1.6 \mathrm{mg} / \mathrm{l} \mathrm{Zn}, 500 \mathrm{mg} / \mathrm{l} \mathrm{La}$ and $1.2 \%(\mathrm{w} / \mathrm{v})$ TCA were prepared. All determinations were made versus a reagent blank containing $500 \mathrm{mg} / \mathrm{l} \mathrm{La}$ and $1.2 \%$ TCA [18], [22]. The analyses were performed in triplicates.

\section{Sensory evaluation of fermented cowpea milk}

Fifty four (54) untrained panelists turned up for the sensory evaluation based on availability. They were asked to fill in a consent form informing them about the samples and to ascertain their personal commitment in participating in the sensory evaluation. Each panelist was provided with samples of fermented cowpea milk of different flavours, a carrot and a glass of water to cleanse their palates before and in between the tasting. They rated their degree of liking for appearance, aroma, taste, texture and overall acceptability on a nine-point hedonic scale where $1=$ like extremely, $5=$ neither like nor dislike and $9=$ dislike extremely [23].

\section{J. Data management and analysis}

Data was analyzed using Analysis of Variance (ANOVA) with Stata version 12. Mean comparisons for treatments were made using Bonferroni tests. Significance level was set at $\mathrm{P} \leq 0.05$.

\section{RESUlTS AND DisCUSSION}

\section{A. Growth of probiotic bacteria in starter cultures}

Fermentation of cowpea with probiotic bacteria may produce benefits related to live bacteria in the body and/or beneficial metabolites produced by the bacteria in the food. For a product to be considered probiotic based on live microorganisms, the product should have a high population of the microorganisms, not less than $10^{6}$ cells per $\mathrm{ml}$ to ensure survival of a good number as they travel through the harsh environment in the stomach. Thus, the populations of bacteria that were attained by cowpea fermentation were determined, as well as the changes in populations during storage.

Initial inocula ranged from $\log 103.1 \pm 0.3 \mathrm{cfu} / \mathrm{ml}$ to $\log 104.7 \pm 0.5 \mathrm{cfu} / \mathrm{ml}$ (Fig. 2). Any culture was not added to one of the samples. After fermentation, the bacterial counts ranged from $\log _{10} 3.9 \pm 0.7 \mathrm{cfu} / \mathrm{ml}$ to $\log _{10} 7.4 \pm 0.8 \mathrm{cfu} / \mathrm{ml}$ (Figure 3).

Cowpea milk fermented with the three cultures, ABT-5, YF-L 903 and Fiti Yoba GR-1, gave colony counts greater than $\log _{10} 6$ (Fig. 3), the recommended bacterial population for a healthy probiotic product [24]. [25] reported LAB counts in cow's milk fermented with YF-L 903 and ABT-5 cultures to be within the range of $2 \times 10^{7}$ to $2 \times 10^{9}$. Results of the present study show that it is possible to attain final populations of these microorganisms in cowpea milk that are comparable to cow's milk. The increase in log cfu was highest for ABT ( 4 log units) followed by Yoba GR-1 and least in YFL 903 ( $2 \log$ units), and these values were within the range recently reported for the growth of various lactic acid bacteria in soymilk [26]. A control sample without added starter culture was also found to have considerable growth of lactic acid bacteria, attaining a final count of $10^{4}$ when incubated at the fermentation temperature for 24 hours. The species involved were however not characterized.

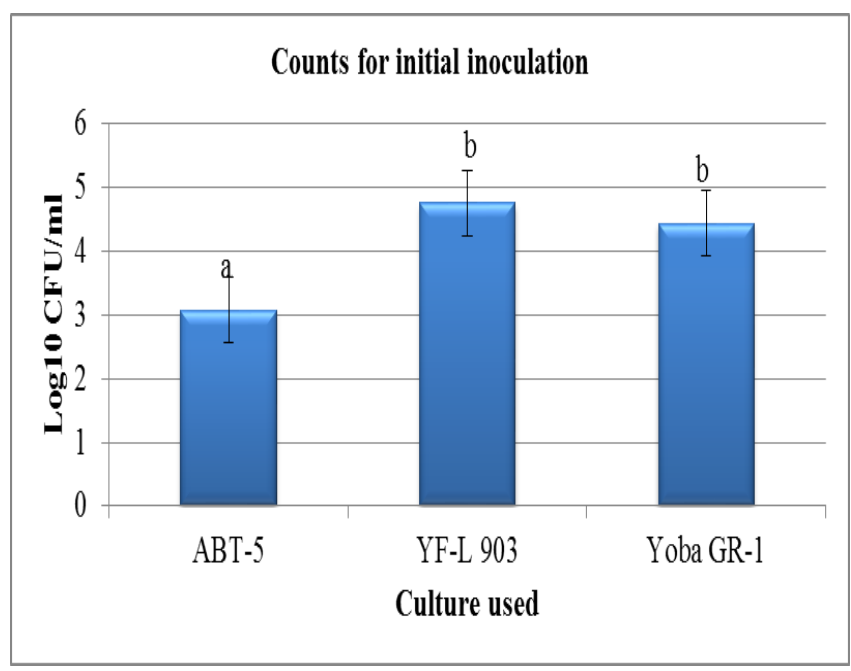

Fig. 2. Initial inoculation colony forming uinit (cfu) counts for cowpea milk inoculated with probiotic cultures.

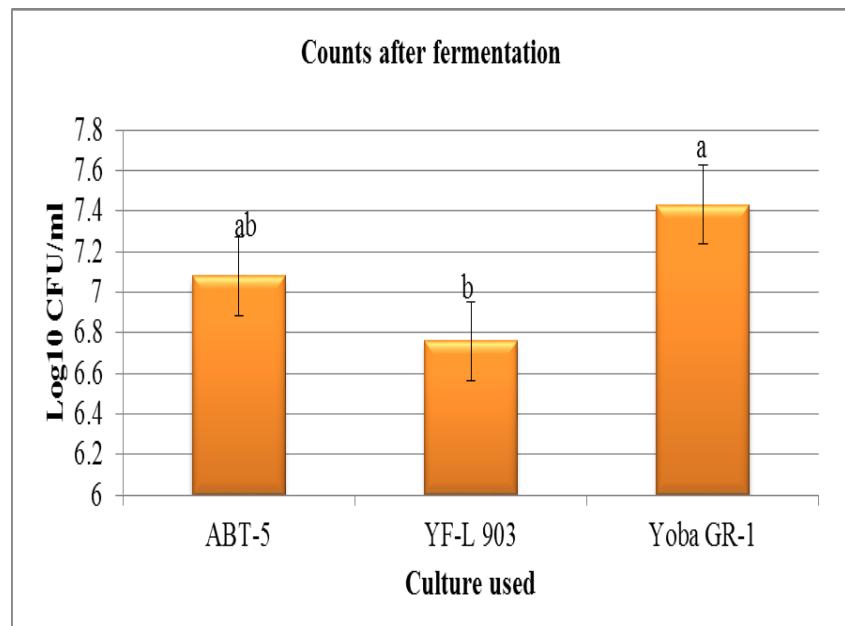

Fig. 3. Cfu counts for cowpea milk inoculated with probiotic bacteria after fermentation for 14 hours at $45^{\circ} \mathrm{C}$. Values are averages of three independent fermentations and bars are standard deviations of averages.

\section{B. Lactic Acid Bacteria survival determination during storage}

Survival rate of the bacteria was monitored over 28 days under refrigeration $\left(4^{\circ} \mathrm{C}\right)$. There was an initial increase in colony forming units in the first two weeks of storage, followed by a slight decline thereafter (Fig. 4). The LAB in the control sample with no culture increased in population from from $\log _{10} 3.94 \mathrm{CFU} / \mathrm{ml}$ to $\log _{10} 6.31 \mathrm{CFU} / \mathrm{ml}$ after 14 days of storage (Fig. 4). Thereafter the number reduced to $\log _{10} 4.11 \mathrm{CFU} / \mathrm{ml}$ on the $28^{\text {th }}$ day of storage. In sample 
with Yoba Gr-1 (containing $L$ rhamnosus GR-1 and $S$. thermophilus), there was an increase in growth of LAB from $\log _{10} 7.43 \mathrm{CFU} / \mathrm{ml}$ to $\log _{10} 8.05 \mathrm{CFU} / \mathrm{ml}$ after 14 days of storage. On the $28^{\text {th }}$ day, the number decreased to $\log _{10} 7.42$ $\mathrm{CFU} / \mathrm{ml}$. This is similar to the previously reported survival of Lactobacillus rhamnosus GG in various leguminous porridges [27].

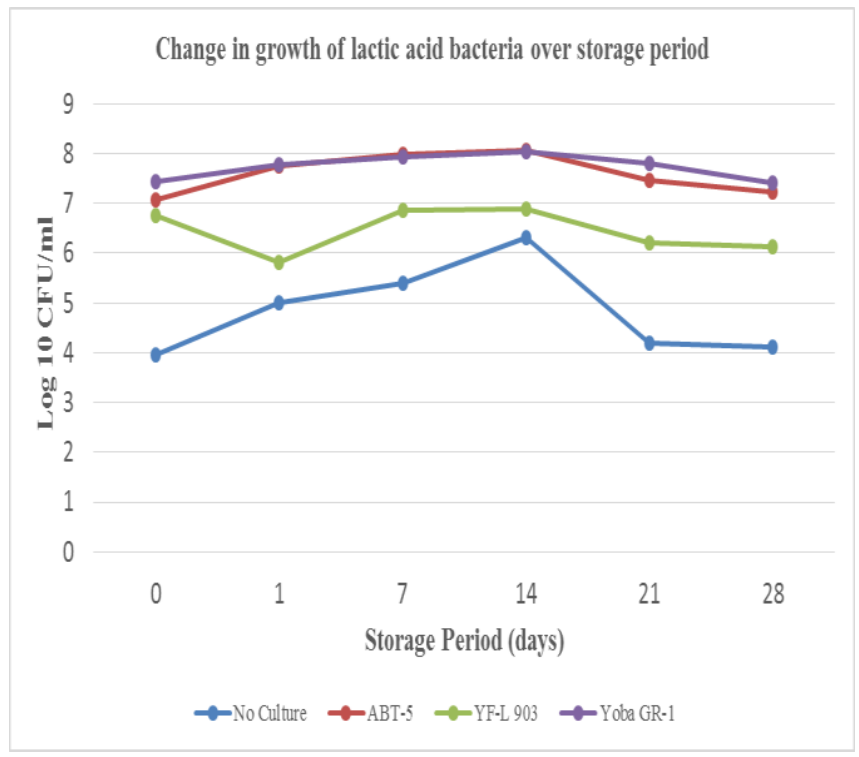

Fig. 4. Shows survival of lactic acid bacteria during storage of the fermented cowpea milk. Values $=$ mean of triplicates $\left(\log _{10} \mathrm{CFU} / \mathrm{ml}\right)$.

LAB growth for sample with YF-L903 increased from $\log _{10} 6.76 \mathrm{CFU} / \mathrm{ml}$ to $\log _{10} 6.89 \mathrm{CFU} / \mathrm{ml}$ after 14 days of storage and a slight decrease in growth $\left(\log _{10} 6.13 \mathrm{CFU} / \mathrm{ml}\right)$ was observed on the $28^{\text {th }}$ day. ABT-5 culture registered $\mathrm{LAB}$ growth of $\log _{10} 8.07 \mathrm{CFU} / \mathrm{ml}$ after 14 days of storage and a slight decrease in growth $\left(\log _{10} 7.22 \mathrm{CFU} / \mathrm{ml}\right)$ after 28 days of storage.

For consumers to have confidence in a product considered probiotic, the product must demonstrate survival of the probiotic bacteria during storage [28]. Suitable probiotic strains for product manufacture are those that can survive and maintain their stability during food production and storage [29]. In this present study, viable cells of probiotic bacteria remained at the levels greater than $\log _{10} 6 \mathrm{cfu} / \mathrm{ml}$, which are the recommended levels for a probiotic product, during a 28 day storage. Several studies have reported reduced number of viable cells of probiotic bacteria during storage. In yoghurt fermented with L. acidophilus, a loss of $\log _{10} 2 \mathrm{cfu} / \mathrm{ml}$ was observed after 28 days of storage [30]. In cow milk fermented with $L$. acidophilus, a loss of $\log _{10}$ $1.5 \mathrm{cfu} / \mathrm{ml}$ was observed after 28 days storage [25] and $\log _{10} 2 \mathrm{cfu} / \mathrm{ml}$ loss in plain yoghurt fermented with $L$. reuteri.

Decline in population of probiotic bacteria could be attributed to reduced metabolic activity of the bacteria because of the long and cold storage temperatures and also post acidification. Low temperatures inhibit growth of Lactic acid bacteria especially those with optimum growth temperature range of $30^{\circ} \mathrm{C}$ to $32^{\circ} \mathrm{C}$ [31]. [32] reported that decline in probiotic bacteria population could be attributed to post acidification, and that the extent of In this study also, the decline in viability was noted to be strain dependent and culture type. The wild type bacteria that grew in the control sample were noted to undergo a sharper decline after the $14^{\text {th }}$ day of storage (Fig. 4).

\section{Proximate composition of fermented cowpea milk}

Apart from knowing the growth and survival of probiotic microorganisms in cowpea milk, it is also of interest to know the nutritional composition of the milk. In this study, the proximate and mineral composition was determined in unfermented cowpea milk and cowpea milk fermented by the different lactic acid bacteria cultures. As shown in Table 2, the moisture content ranged between 92.3 and $92.8 \%$. The moisture content of the cowpea and its fermented products in the current study is consistent and slightly higher than the earlier research done by [33], who reported moisture content of range $71.53-91.22 \%$. Crude fibre was not detected, and this differs from results obtained by [33] who reported a crude fibre content of $0.02-0.09 \%$. Dehulling has been previously reported to greatly reduce crude fibre in legumes [34]. The difference obtained could have been due to loss through fine paste adherence to the cheesecloth used for filtration. Crude fat ranged between 0.3 in the ABT-fermented product and 0.5 in the GT-fermented product, with significance in the differences $(\mathrm{p}<0.05)$. The percentage lipid content obtained for cowpea milk and its fermented products in this study was consistent and in agreement with other researchers [35]-[36] but slightly differs from the findings of [37] that found higher lipid content in fermented cowpea milk in the range of 0.55 $1.34 \%$.

The percentage ash content in this present study was found to be 0.2 , with no significant change after fermentation (Table 1). This falls within the range reported by [38] who reported ash content of cowpea to be within the range $0.21-1.09 \%$. The ash content increased with fermentation and this can be attributed to loss of dry matter during fermentation as microorganisms degrade carbohydrates and proteins [39].

The percentage protein content ranged between 1.5- 1.7 (Table 1). This was slightly lower than the protein content reported by [36] who reported a percentage protein content of 1.9-2.5. Effect of fermentation on proteins has remained inconsistent in various studies.

Several studies have reported protein increase after fermentation [33]-[35], [38]-[40], while other have reported decrease in proteins and some amino acids after fermentation [40]-[41] and they attributed this to the fact that fermenting microorganisms also use amino acids which could lower the protein content and quality of fermented foods.

An insignificant decrease $(\mathrm{P}<0.05)$ was observed for carbohydrate content after fermentation, with YFL-903 culture leading to the highest decrease of $7.1 \%$. 
TABLE 1: Chemical composition of unfermented and fermented cowpea milk

\begin{tabular}{lllllll}
\hline Sample & \multicolumn{5}{c}{ \% Composition } \\
\hline \multirow{3}{*}{ Moisture } & Crude fat & $\begin{array}{c}\text { Crude } \\
\text { fibre }\end{array}$ & Ash & Protein & Carbohydrate \\
\cline { 2 - 7 } & $92.3 \pm 0.06^{\mathrm{a}}$ & $0.5 \pm 0.02^{\mathrm{de}}$ & ND & $0.2 \pm 0.01^{\mathrm{a}}$ & $1.7 \pm 0.01$ & $5.3 \pm 0.01^{\mathrm{a}}$ \\
ABT & $92.5 \pm 0.15^{\mathrm{b}}$ & $0.3 \pm 0.01^{\mathrm{a}}$ & ND & $0.2 \pm 0.20^{\mathrm{a}}$ & $1.5 \pm 0.01$ & $5.2 \pm 0.01^{\mathrm{a}}$ \\
DT & $92.8 \pm 0.12^{\mathrm{b}}$ & $0.4 \pm 0.01^{\mathrm{b}}$ & ND & $0.2 \pm 0.01^{\mathrm{a}}$ & $1.6 \pm 0.01$ & $5.1 \pm 0.02^{\mathrm{a}}$ \\
NC & $92.5 \pm 0.01^{\mathrm{b}}$ & $0.4 \pm 0.02^{\mathrm{b}}$ & ND & $0.2 \pm 0.01^{\mathrm{a}}$ & $1.5 \pm 0.01$ & $5.5 \pm 0.01^{\mathrm{a}}$
\end{tabular}

$\mathrm{NC}=$ unfermented cowpea milk, ABT = cowpea milk fermented with ABT-5 culture, GT = cowpea milk fermented with Yoba fiti GR-1 culture, DT = cowpea milk fermented with YFL-903 culture, ND = Not detected.

Values are mean \pm standard deviations of triplicates. Values with different letter superscript in the same column are significantly different at (p<0.05) based on Bonferroni tests.

Fermentation activates starch-hydrolysing enzymes such as $\alpha$-amylase and maltase which degrade starch into maltodextrins and simple sugars respectively [42]. The glucose released during fermentation is a preferred substrate for microorganisms and could partly explain the decrease in carbohydrates [41]. Current study reported an insignificant decrease in total carbohydrate after fermentation, attributable to the use of sugars as substrates during fermentation [41]. Table 2 below shows the mineral composition of the fermented cowpeas. These results were in line with a research study by [22] who reported over $90 \%$ decrease in calcium and $50 \%$ reduction in iron after fermentation of cowpea flour. The results are also consistent with study by [33] who reported zinc content (7.33$13.74 \mathrm{mg} / 100 \mathrm{~g})$ and magnesium content (16.53-22.84 $\mathrm{mg} / 100 \mathrm{~g})$. [43] reported iron content of cowpeas in the range of $9.9-23.8 \mathrm{mg} / \mathrm{kg}$; calcium $320-1112.9 \mathrm{mg} / \mathrm{kg}$ and zinc $17.1-32.2 \mathrm{mg} / \mathrm{kg}$. This was slightly higher than the results in present study.

TABLE 2: Mineral composition of unfermented and fermented cowpea milk

\begin{tabular}{lcccc}
\hline Sample & \multicolumn{3}{c}{ Mineral elements (mg/100g) } \\
& Zinc (Zn) & Calcium(Ca & Iron (Fe) & $\begin{array}{c}\text { Magnesium } \\
(\mathrm{Mg})\end{array}$ \\
\hline NC & $0.07 \pm 0.01^{\mathrm{a}}$ & $0.02 \pm 0.01^{\mathrm{b}}$ & $0.49 \pm 0.07^{\mathrm{a}}$ & $17.62 \pm 0.07^{\mathrm{a}}$ \\
ABT & $0.13 \pm 0.02^{\mathrm{a}}$ & $0.01 \pm 0.01^{\mathrm{b}}$ & $0.34 \pm 0.03^{\mathrm{a}}$ & $20.62 \pm 0.34^{\mathrm{a}}$ \\
GT & $0.16 \pm 0.01^{\mathrm{a}}$ & $0.01 \pm 0.01^{\mathrm{b}}$ & $0.38 \pm 0.04^{\mathrm{a}}$ & $20.35 \pm 0.11^{\mathrm{a}}$ \\
DT & $0.13 \pm 0.01^{\mathrm{a}}$ & $0.01 \pm 0.01^{\mathrm{b}}$ & $0.32 \pm 0.01^{\mathrm{a}}$ & $18.18 \pm 0.14^{\mathrm{a}}$ \\
\hline
\end{tabular}

Symbols as in Table 1

Values with different letter superscript in the same column are significantly different at $(\mathrm{p}<0.05)$ based on Bonferroni tests.

\section{Sensory evaluation}

Sensory evaluation helps in making predictions on customer acceptance and preferences of a new product. It is also important during upgrade of an existing product due to changes in market trends or data collected from consumers [44]. In the present study, sensory evaluation was done for fermented cowpea milk with sugar \& flavour and without sugar to test the preference based on sweetness. Rating was done for appearance, aroma, taste and texture on anine-point hedonic scale where $1=$ like extremely, $5=$ neither like nor dislike and $9=$ dislike extremely [23].

Table 3 shows that no significant differences were observed for sensory attributes of taste, texture and overall acceptability. However, aroma and appearance had significant differences among the samples.

The differences observed in texture and flavor can be attributed to the characteristics of the individual cultures used. These results are in line with studies done by [6], [25],
[33], [45]. [45] reported that storage time and probiotic strains affect sensory properties of yoghurts. They found out that addition of $L$. acidophilus and $B$. bifidum to yoghurts significantly $(\mathrm{P}<0.05)$ affects acidity and taste of yoghurt, but not odour, texture and general acceptability. The current study is in agreement with the above argument. [46] stated that presence of probiotics especially Bifidobacterium genus in the yoghurt can contribute to rejection of the product due to excess acidity and more viscous texture. Overall acceptability score of the product was $4.7-5.3$ indicating dislike to like slightly. Therefore, despite the potential benefits, more work should be done to improve the sensory and overall acceptability.

TABLE 3: Sensory evaluation of fermented cowpea milk

\begin{tabular}{lccccc}
\hline Sample & Aroma & Taste & Texture & Appearance & $\begin{array}{c}\text { Overall } \\
\text { Acceptability }\end{array}$ \\
& & & & & $5.1 \pm 0.9^{\mathrm{g}}$ \\
\hline $\mathbf{E}_{\mathbf{i}}$ & $4.9 \pm 1.4^{\mathrm{a}}$ & $4.8 \pm 1.4^{\mathrm{c}}$ & $4.1 \pm 1.4^{\mathrm{d}}$ & $4.0 \pm 1.5^{\mathrm{e}}$ & $5.9 \pm 1.1^{\mathrm{g}}$ \\
$\mathbf{E}_{\mathbf{i i}}$ & $4.9 \pm 1.6^{\mathrm{a}}$ & $4.9 \pm 1.9^{\mathrm{c}}$ & $4.3 \pm 0.8^{\mathrm{d}}$ & $4.0 \pm 1.8^{\mathrm{ef}}$ & $4.0^{\mathrm{a}}$ \\
$\mathbf{F}_{\mathbf{i}}$ & $4.6 \pm 1.6^{\mathrm{a}}$ & $5.1 \pm 2.0^{\mathrm{c}}$ & $4.4 \pm 1.0^{\mathrm{d}}$ & $4.1 \pm 1.7^{\mathrm{e}}$ & $5.3 \pm 0.2^{\mathrm{g}}$ \\
$\mathbf{F}_{\mathbf{i i}}$ & $4.8 \pm 1.3^{\mathrm{a}}$ & $4.9 \pm 1.6^{\mathrm{c}}$ & $4.2 \pm 1.3^{\mathrm{d}}$ & $3.7 \pm 1.3^{\mathrm{ef}}$ & $5.0 \pm 1.0^{\mathrm{g}}$ \\
$\mathbf{G}_{\mathbf{i}}$ & $5.1 \pm 1.4^{\mathrm{b}}$ & $5.0 \pm 1.6^{\mathrm{c}}$ & $4.1 \pm 1.1^{\mathrm{d}}$ & $3.9 \pm 1.4^{\mathrm{ef}}$ & $5.1 \pm 1.2^{\mathrm{g}}$ \\
$\mathbf{G}_{\mathbf{i i}}$ & $5.1 \pm 1.5^{\mathrm{b}}$ & $5.3 \pm 1.9^{\mathrm{c}}$ & $4.4 \pm 1.0^{\mathrm{d}}$ & $4.5 \pm 1.7^{\mathrm{e}}$ & $5.3 \pm 1.3^{\mathrm{g}}$ \\
$\mathbf{H}_{\mathbf{i}}$ & $4.8 \pm 1.5^{\mathrm{ab}}$ & $5.0 \pm 1.9^{\mathrm{c}}$ & $4.4 \pm 1.0^{\mathrm{d}}$ & $4.2 \pm 1.7^{\mathrm{e}}$ & $4.9 \pm 0.4^{\mathrm{g}}$ \\
$\mathbf{H}_{\mathbf{i i}}$ & $5.0 \pm 1.4^{\mathrm{ab}}$ & $5.1 \pm 1.4^{\mathrm{c}}$ & $4.2 \pm 1.3^{\mathrm{d}}$ & $4.0 \pm 1.5^{\mathrm{e}}$ & $4.7 \pm 1.2^{\mathrm{g}}$ \\
\hline
\end{tabular}

${ }^{*} \mathrm{E}_{\mathrm{i}}=$ ABT-5 Vanilla, $\mathrm{E}_{\mathrm{ii}}=$ ABT-5 Strawberry, $\mathrm{F}_{\mathrm{i}}=$ YF-L 903 Vanilla, $\mathrm{F}_{\mathrm{ii}}=$ YF-L 903 Strawberry, ${ }^{*} \mathrm{H}_{\mathrm{i}}=$ Yoba GR-1 Vanilla, $\mathrm{H}_{\mathrm{ii}}=$ Yoba GR-1 Strawberry, $\mathrm{G}_{\mathrm{i}}=$ No culture vanilla, $\mathrm{G}_{\mathrm{ii}}=$ No culture Strawberry

Values are mean \pm standard deviations of triplicates. Values with different letter superscript in the same column are significantly different at $(\mathrm{p}<0.05)$ based on Bonferroni tests.

\section{CONCLUSIONS AND RECOMMENDATIONS}

The study has demonstrated that nutritional quality of cowpea milk can be achieved through fermentation. Also, cowpea milk fermented with lactic acid bacteria produce a yoghurt-like product that can be sweetened to taste and be acceptable to consumers. The study therefore recommends that:

1. More work should be done to improve the sensory acceptability of the products

2. Their potential health benefits should be determined through in vivo studies.

\section{CONFLICT OF INTEREST}

The authors declare that there is no conflict of interest.

\section{ACKNOWLEDGEMENT}

The authors are grateful to the Netherlands Initiative for Capacity Building in Higher Education (NICHE) under the NICHE KEN 189 Project, for the funding of the study. The 
fundamental support provided by University of EldoretKenya, Jomo Kenyatta University of Agriculture and Technology (JKUAT), Kenya and the Manager, NICHE KEN 189 Project (Prof. Julius Onyango Ochuodho) for this work is highly acknowledged.

\section{REFERENCES}

[1] Muller, O. (2005). Malnutrition and health in developing countries. Canadian Medical Association Journal, 173(3), 279-2, 173(3), 2-3.

[2] Minelli, E. B., \& Benini, A. (2008). Relationship between number of bacteria and their probiotic effects. Microbial Ecology in Health and Disease, 20(4), https://doi.org/10.1080/08910600802408095

[3] Gowshall, M., \& Taylor-robinson, S. D. (2018). The increasing prevalence of non-communicable diseases in low-middle income countries : the view from Malawi. International Journal of General Medicine, 255-264.

[4] Tuso, P. J., Ismail, M. H., Ha, B. P., \& Bartolotto, C. (2013). Nutritional Update for Physicians : Plant-Based Diets, 17(2), 61-66.

[5] Somasundaram, N. P., \& Kalupahana, N. S. (2016). Populationbased dietary approaches for the prevention of noncommunicable diseases. WHO South East Asia Journal of Public Health, 5(April), 22-26.

[6] Winham, D. M., \& Hutchins, A. M. (2011). Perceptions of flatulence from bean consumption among adults in 3 feeding studies, 1-9.

[7] Madodé, Y. E., Nout, M. J. R., Bakker, E. J., Linnemann, A. R., Hounhouigan, D. J., \& van Boekel, M. A. J. S. (2013). Enhancing the digestibility of cowpea (Vigna unguiculata) by traditiona processing and fermentation. LWT - Food Science and Technology, 54(1), 186-193. https://doi.org/10.1016/j.lwt.2013.04.010

[8] Mukisa, I. M., Byaruhanga, Y. B., Muyanja, C. M. B. K., Langsrud, T., \& Narvhus, J. A. (2017). Production of organic flavor compounds by dominant lactic acid bacteria and yeasts from Obushera, a traditional sorghum malt fermented beverage. Food Science and Nutrition, 5(3), 702-712. https://doi.org/10.1002/fsn3.450

[9] Singh, R., Kumar, M., Mittal, A., \& Kumar, P. (2017). Microbial metabolites in nutrition, healthcare and agriculture. 3 Biotech, 7(1), 1-14. https://doi.org/10.1007/s13205-016-0586-4

[10] Kumar, M., Rakesh, S., Nagpal, R., Hemalatha, R., Ramakrishna, A., Sudarshan, V., ... Kumar, R. (2013). Probiotic Lactobacillus rhamnosus GG and Aloe vera gel improve lipid profiles in hypercholesterolemic rats. Nutrition, 29(3), 574-579. https://doi.org/10.1016/j.nut.2012.09.006

[11] Ellegård, L., Andersson, H., \& Bosaeus, I. (1997). Inulin and oligofructose do not influence the absorption of cholesterol, or the excretion of cholesterol, $\mathrm{Ca}, \mathrm{Mg}, \mathrm{Zn}, \mathrm{Fe}$, or bile acids but increases energy excretion in ileostomy subjects. European Journal of Clinical Nutrition, 51(1), 1-5. https://doi.org/10.1038/sj.ejcn.1600320

[12] Jayathilake, C., Visvanathan, R., Deen, A., Bangamuwage, R., Jayawardana, B. C., Nammi, S., \& Liyanage, R. (2018). Cowpea: an overview on its nutritional facts and health benefits. Journal of the Science of Food and Agriculture, 98(13), 4793-4806. https://doi.org/10.1002/jsfa.9074

[13] Victoria O. Ndubuaku, A. C. U. and D. 0. N. (1989). Flatulence and other Discomforts Associated with Consumption of Cowpea (Vigna unguiculata), 171-181.

[14] Khan, Z. B. and K. (1992). Reduction of Flatulence-Causing Sugars by High Temperature Extrusion of Pinto Bean High Starch Fractions, 57(3), 771-773

[15] Zartl, B., Silberbauer, K., Loeppert, R., Viernstein, H., Praznik, W., \& Mueller, M. (2018). Fermentation of non-digestible raffinose family oligosaccharides and galactomannans by probiotics. Food and Function, 9(3), 1638-1646. https://doi.org/10.1039/c7fo01887h

[16] Deogade, S. C. (2015). Probiotics : Contributions to Oral and Dental Health Probiotics: Contributions to Oral and Dental Health. Oral Health and Dental Management, 14(No. 3 June).

[17] Reid, G. (2017). The development of probiotics for women 's health. Can. J. Microbiol., 277(December 2016), 269-277.

[18] Anino, C., Onyango, A. N., Imathiu, S., Maina, J., \& Onyangore, F. (2019). Chemical composition of the seed and ' milk' of three common bean ( Phaseolus vulgaris L ) varieties. Journal of Food Measurement and Characterization, $O(0), \quad 0$ https://doi.org/10.1007/s11694-019-00039-1

[19] IDF. (2018). Internati onal Dairy Federati on ( IDF ).

[20] AOAC, Official Methods of Analysis of AOAC International, 17th edn. (Association of Official Analytical Chemists (AOAC) International, Gaithersburg, 2000)

[21] Mosisa, M. T., \& Tura, D. C. (2017). Effect of Processing on
Proximate and Mineral Composition of Hepho , a Black Effect of Processing on Proximate and Mineral Composition of Hepho , a Black Climbing Bean ( Lablab purpureus L .) Flour. Journal of Food and Nutrition Sciences, 5(January), 16-22. https://doi.org/10.11648/j.jfns.20170501.13

[22] Difo, H. V, Onyike, E., Ameh, D. A., Ndidi, U. S., \& Njoku, G. C. (2014). Chemical Changes during Open and Controlled Fermentation of Cowpea (Vigna unguiculata) Flour. International Journal of Food Nutrition and Safety , 5(51), 1-10.

[23] Mawunyo, K., Fidelis, K., Emmanuel, A. O., Betty, A. B., \& Firibu, S. K. (2014). Nutritional and sensory characterization of full fat and partially defatted peanut soy milk yoghurt, 3(3), 187-193. https://doi.org/10.11648/j.ijnfs.20140303.19

[24] [24] H.-S. Shin, J.-H. Lee, J.J. Pestka, \& Z. U. (2000). Growth and Viability of Commercial Bifidobacterium spp in Skim Milk Containing Oligosaccharides and Inulin, 65(5), 884-887.

[25] E. Mani-López, E . Palou, \& A. L.-M. (2014). probiotic viability and storage stability of yogurts and fermented milks prepared with several mixtures of lactic acid bacteria. Journal of Dairy Science, 97(5), 2578-2590. https://doi.org/10.3168/jds.2013-7551

[26] Niyibituronsa, M., Onyango, A. N., Gaidashova, S., Imathiu, S., Boevre, M. De, Leenknecht, D., ... Raes, K. (2019). The Growth of Different Probiotic Microorganisms in Soymilk from Different Soybean Varieties and their Effects on Anti-oxidant Activity and Oligosaccharide Content, $8(1), \quad 41-51$. https://doi.org/10.5539/jfr.v8n1p41

[27] Petruláková, M., \& Valík, L. (2015). Evaluation of legumes as a substrate for probiotic strain Lactobacillus rhamnosus GG. Acta Alimentaria, 44(2), 268-275. https://doi.org/10.1556/066.2015.44.0004

[28] Kort, R., Westerik, N., Serrano, L. M., Douillard, F. P., \& Gottstein, W. (2015). A novel consortium of Lactobacillus rhamnosus and Streptococcus thermophilus for increased access to functional fermented foods. Microbial Cell Factories. https://doi.org/10.1186/s12934-015-0370-x

[29] Chin, K. K. \& J. (2000). Survival and therapeutic potential of probiotic organisms with reference to Lactobacillus acidophilus and Bifidobacterium spp ., 80-88.

[30] Damin, M. R., Minowa, E., \& Alcântara, M. R. (2007). EFFECT OF COLD STORAGE ON CULTURE VIABILITY AND SOME RHEOLOGICAL PROPERTIES OF FERMENTED MILK PREPARED WITH YOGURT AND PROBIOTIC BACTERIA, 39(2008), 40-55.

[31] Sengupta, R., Altermann, E., Anderson, R. C., Mcnabb, W. C., Moughan, P. J., \& Roy, N. C. (2013). The Role of Cell Surface Architecture of Lactobacilli in Host-Microbe Interactions in the Gastrointestinal Tract, 2013.

[32] Shah, N. P. (2000). Probiotic Bacteria: Selective Enumeration and Survival in Dairy Foods. Journal of Dairy Science, 83(4), 894-907. https://doi.org/10.3168/jds.S0022-0302(00)74953-8

[33] Chavan, J. K., Kadam, S. S., \& Beuchat, L. R. (2009). Nutritional improvement of cereals by fermentation. https://doi.org/10.1080/10408398909527507

[34] Hag, M. E. El, Tinay, A. H. El, \& Yousif, N. E. (2002). Effect of fermentation and dehulling on starch, total polyphenols, phytic acid content and in vitro protein digestibility of pearl millet, 77, 193-196.

[35] Duodu, K. G., Taylor, J. R. N., Belton, P. S., \& Hamaker, B. R. (2003). Factors affecting sorghum protein digestibility. Journal of Cereal Science, 38, 117-131. https://doi.org/10.1016/S07335210(03)00016-X

[36] Inobeme, A.; 1Nlemadim, A.B; 2Obigwa, P.A; 1Ikechukwu, G. and 1Ajai, A. . (2014). Determination of Proximate and Mineral Compositions of White Cowpea Beans ( Vigna Unguiculata ) Collected From Markets in Minna , 5(8), 502-504.

[37] Ojokoh, A. O., Daramola, M. K., \& Oluoti, O. J. (2013). Effect of fermentation on nutrient and anti-nutrient composition of breadfruit (Treculia africana ) and cowpea ( Vigna unguiculata ) blend flours, 8(27), 3566-3570. https://doi.org/10.5897/AJAR12.1944

[38] Awika, J., Scientists, C., Talcott, S., Singh, B. B., Rooney, L. Shindano, J., ... Africa, S. (2011). Increasing Utilization of Cowpeas to Promote Health and Food Security in Africa.

[39] Day, C. N., \& Morawicki, R. O. (2018). Effects of Fermentation by Yeast and Amylolytic Lactic Acid Bacteria on Grain Sorghum Protein Content and Digestibility, 2018.

[40] Pranoto, Y., Anggrahini, S., \& Efendi, Z. (2013). Effect of natural and Lactobacillus plantarum fermentation on in - vitro protein and starch digestibilities of sorghum fl our. Food Bioscience, 2, 46-52. https://doi.org/10.1016/j.fbio.2013.04.001

[41] Osman, M. A. (2011). Effect of traditional fermentation process on the nutrient and antinutrient contents of pearl millet during 
preparation of Lohoh. Journal of the Saudi Society of Agricultural Sciences, 10(1), 1-6. https://doi.org/10.1016/j.jssas.2010.06.001

[42] Nkhata, S. G., Ayua, E., Kamau, E. H., \& Shingiro, J.-B. (2018)

Fermentation and germination improve nutritional value of cereals and legumes through activation of endogenous enzymes. Food Science \& Nutrition, (September), 1-13. https://doi.org/10.1002/fsn3.846

[43] Mamiro, P. (2011). Nutritional quality and utilization of local and, $11(1)$.

[44] Ibrahim, F. D., Nmadu, J. N., Baba, K. M., Danbaba, N., \& Ibrahim, P. A. (2014). Assessment of Consumer Preference for Cowpea Quality Characteristics and Price Trends in Niger State , Nigeria, 76 , 105-112. https://doi.org/10.7763/IPCBEE.

[45] Turgut, T., \& Cakmakci, S. (2018). Probiotic Strawberry Yogurts : Microbiological , Chemical and Sensory Properties, 64-70. https://doi.org/10.1007/s12602-017-9278-6

[46] Faria, A. F., Cruz, A. G., Cadena, R. S., Oliveira, A. F., Cavalcanti, R. N., Bona, E., ... Silva, A. P. D. A. (2011). Consumer acceptability and purchase intent of probiotic yoghurt with added glucose oxidase using sensometrics, artificial neural networks and logistic regression, 64(4), 549-556. https://doi.org/10.1111/j.14710307.2011.00722.x. 